\title{
letters from beirut
}

In summer 2006 I returned to Lebanon for a third time. I had lived in Beirut for almost a year in 2002-2003, during which time I fell in love with the city, as so many people do-the generosity, resilience and joie de vivre of so many Lebanese people, the lively artistic scene, the intensity with which so many historical and international forces cross this small country. I built strong friendships then. I returned in 2004, and again in June 2006, this time to study Arabic at the American University of Beirut.

On 14 July, in response to Hizballah's action of taking two Israeli soldiers hostage and shooting across the Lebanese-Israeli border, Israel began an intense bombardment of Lebanese infrastructure, starting with the airport, as well as places where Hizballah supporters lived. A privileged outsider waiting to be evacuated, I was also helpless, afraid, and furious at the pro-Israeli tone of the international media. So I wrote daily letters to family, friends, and a growing email list of interested people. This is an edited version.

\section{— SUbJect: LetTER FROM Beirut JULy 16}

Oh my dear ones-

This morning I was eating some olives Farida gave me when I burst into tears. Last night I didn't hear the bombs from my basement apartment, but yesterday there was a lot of bombing and firing up close: the Boom-Crack of naval artillery, the wall-shaking Boom of bombs, some pop pop pops I don't know what they are, and the constant low thunder of their planes circling just to spook us. And the echo. 
Since I've been living here I've been enjoying watching my neighbors on the balcony opposite: the young man who comes out on the balcony to pray and goes in to watch the Mondial on TV, the Sri Lankan nanny playing with her young charge on the balcony below, the elderly fellow who waters his luxuriant plants every day. People still need to eat and look after the kids and the flowers in wartime.

At the little shop downstairs of Mr. Fouad where I buy big bottles of water, he offers me a chair and cigarettes so I can watch the news with him. He turns to an American channel for me but I can't bear it, it's all about where is Nasrallah hiding, like he is a wild animal in uncharted territory, not the thickly inhabited human country that the Israelis are blasting to smithereens. Fouad tells me, 'I love Bush'. He has a brother in Houston whose two sons are in the army in Iraq. I don't tell him the depth of my bitter hatred for Bush. (BTW the best source for news from here is the Lebanon Daily Star online.)

It looks like the Canadians have finally got their shit together to put us on a boat to Cyprus, though the details are not yet clear. As I howled to my mother on the phone, those are American bombs falling on the city, American artillery shooting at us, paid for by American money, and I'll be damned if I dust off my US passport to get onto their stinking ship. Until recently leaving the city was more dangerous than staying, with the roads being bombed, and it still is more dangerous than not moving at all.

But in any case it is obscene, Israel giving a brief safe passage from the Beirut port for foreign ships, so that once all we foreigners are gone they can bomb the city to oblivion. I feel guilty, as though I were part of a protective shield for Beirut that is being pulled away. I think Israel's goal is not just to get Nasrallah (indeed their purpose changes every day) but to punish Lebanon for its recovery, slowly and finally, from the civil war, the changes made by Hariri before he was assassinated, to build connections with Gulf capital, on one scale, and install wonderful cheap public telephones, on another. They dropped leaflets on the city yesterday-in the sky it looked like a huge flock of tiny birds—with a picture of people fleeing from bombs, an ugly portrait of Nasrallah as a serpent, and a warning in Arabic: 'The resistance protects the country...? The country is the victim of the resistance!'

Here's my understanding of Hizb Allah. A lot of people, not only Shi'a, like the party, or used to, because they're the only ones who have successfully defended the country against Israeli invasion; they appeal to an aggrieved nationalism, and their heroic TV spots are rousing. Plus, for many years Hizb Allah was the only organization that cared for the poor Shi'a of the south while the government ignored them: the party put in roads and hospitals and schools. Now however they seem to be capitalizing on that patriotic feeling when in fact they're a cat's paw for Syria and Iran. Why the hell, if this is a fight between those countries and Israel, is it being played out on Lebanese turf? Why are the Israelis bombing an ambulance, bombing a bus full of civilians fleeing to the Syrian border (this is why our escape 
route is by boat), and despite its famous surgical accuracy missing the Hizb Allah radio station and bombing an apartment building? So many people dead and wounded! If you are unlucky enough to live in southern Lebanon or the southern suburbs of Beirut, everything is destroyed! Lebanon-beautiful beloved Lebanon with its cynical, smart, generous people is like a precious toy that a lot of big unruly children are fighting over, tugging it till it breaks.

My friend Hani, the taxi driver, lives in Jiyeh where the Israelis have bombed the power plant into mile-high black clouds. He sent an SMS that he and his children are out of their house but they are safe.

Last night I went to my friend Ahmad's bar to hunker down together, listen to music and joke. He likes the Eagles but he put on the lovely oriental strains of Ziad Rahbani for me. We were Lebanese, Norwegian, Egyptian, Bulgarian, Canadian, and American. Young Victor the Bulgarian student had printed off a bunch of his favorite poems and was handing them out like talismans. We told jokes about fate and undignified deaths. I gave the example of falling off the uneven Beirut sidewalk while distracted by the sound of the bombing (as I did yesterday) and smashing myself up. Alice's example was an old Norwegian woman who broke her thighbone, not slipping on the ice, but falling off a camel. But this light talk is our way of dealing with the terrible shots on the TV of people injured, screaming, exposed in their pain.

Love to all,

Laura

\section{— Subject: Letter from Beirut July 17}

Hi dear friends-

Bless Chirac, the only Western leader with any sense!

Slept well in my basement apartment, only heard 2 very big booms at 5 in the morning. Another one just now, it's 11 . And another, shaking the building.

$57 \%$ of CNN voters (down from 63\% earlier today) think the Israeli Offensive on Lebanon is justified; please give your opinion by voting on their Quickvote: http://edition.cnn.com/ 2006/WORLD/meast/07/13/mideast/index.html

You can also write to the PM and Foreign Minister or to your US equivalents and tell them Israel's offensive is killing innocent Lebanese and bombing the country back 20 years, at cost to this country of $\$ 8$ billion a day-seems a pretty idiotic way to go after Hizballah, which does not represent Lebanon. It appears that Israel is using phosphorous incendiary bombs, which suck the air out of a building and don't stop burning, on civilians, this is illegal of course. 
Of course you are worried about me, but know that I am still safe living in Ras Beirut, which with awful irony is the safest neighborhood in Beirut because there are so many of us foreigners here. I fear terribly for my friends here once we should leave. Yesterday I packed with manic calm, putting my stuff into 4 bags, one of which I could jettison with a twinge (my books! My Arabic homework!), one that I would be quite sad to lose (my clothes and the pretty souvenirs I've bought for you from Cairo and Beirut), one that I really do not want to lose because it is my brain (my computer) but not my life, and for emergencies my purse (my Canadian passport and the hated-sorry American dear ones—expired US passport, my wallet, dollars, my blue notebook, Lebanese phone, that wonderful invention the USB stick, sleeping pills, earplugs, sunscreen, camera, and, to cheer people up, lipstick).

I am hanging onto my beautiful Hans Wehr (Librairie du Liban) Arabic-English dictionary, alphabetized by the root of the word. I love how from one three-consonant Arabic root all the words unfold, transforming into all their variations. And I like the onomatopoeia of Arabic, how words sound like their meaning: the soft insistence of Hubb, love (an aspirated 'h', and the 'u' not as in 'hubcap' but as in 'furry'); the exhalation of 'raaha', comfort; the finality of inTaqala, to be cut off; the harshness of qaSafa, bombardment. And I swear, on every other page there is an entirely different word whose meaning is 'to look up in the dictionary'! An erudite product placement perhaps?

Victor and Carole took off in a taxi to Turkey yesterday.

Last night I stayed inside the friendly bar of Ahmad, Ahmad, and Alice. Ahmad was playing The Eagles as usual. Bassem showed up, the sweet grumpy swim instructor with whom I sat through the Gulf War at Ahmad's previous bar called Walimat. They are so sad, so devastated for their country that all they can do is smile softly, Bassam's glass full of neat vodka. Had a long chat with a leathery veteran UN negotiator, Timur Goksel, who worked in the south for 20 years. He says Hizballah does still represent the sentiments of many people in the Arab world, not only Shi'a, because people in these countries have been crushed again and again by the West and their own governments, and Hizballah is the only resistance-it gives people pride. Al-Jazeera was on TV with news from here as detailed as a Lebanese TV station; Timur said, however, that no news of the war on Lebanon shows on Al Jazeera in places like Egypt and Jordan-'so the people won't get ideas'. I asked Timur if he misses Turkish food; he said in the Armenian neighborhood of Bourj Hammoud there are lots of Turks, migrant workers and also some ladies who married Lebanese bank managers of the generation who sought the prestige of the Ottoman connection; Turks and Armenians live there together and eat the same food. But he does miss the sound of the Turkish oud, sadder and more soulful and technically more difficult than the Lebanese oud.

Alice is Norwegian and married Ahmad ('Ahmad taani', I call him, the other Ahmad, as I know Ahmad 1 better) and they started this nice little resto-bar. She is racked with anxiety: 
should she go to Norway and be safe and not a burden on Ahmad, who lived through the civil war and has the calm of a saint? (okay I know not all saints are calm) But what if it escalates and she can't return, and he can't get a visa out? If the neighborhood empties of foreigners and the siege drags on, will gangs come out like during the civil war? It will take 25 years to rebuild the economy, and in 25 years she'll be 75 . What about their nice little restaurant with the international flags and Escher prints on the walls?

Had a coffee with Sohail in his shop. Business is brisk-he's out of Coke and Marlboro Red and almost out of Pepsi!

Hani hasn't responded to my messages. I fell for his usual over-sanguineness when he last SMSed me 2 days ago 'Things are fine till now. I am out of the house with my children'-now I realize he meant, now things are not fine. So scared for him, dear verbose infuriating Hani!

Love to all

Laura

\section{— Subject: Letter from beirut July 18}

Israel continues to bomb civilian targets. They told people in the south to run for their lives, but it is bombing any remaining roads they might take; yesterday it killed 10 people escaping in a bus across a bridge in the south. The 38,000 refugees are staying in schools; they bombed a school. 204 Lebanese people are dead as of this morning, all but 14 of them civilians (so why does the Toronto Globe and Mail state the numbers of the dead and then do an interview with the family of an Israeli soldier who died on duty??). And it breaks my heart even more to think of the suffering of the wounded. Everything of use to Lebanese people is being destroyed, including gas reserves.

Timur, who worked for the UN in the South for 25 years and knows Hizballah very well, says Hizballah does not have a military base. He says their 15,000 or so missiles are hidden one at a time-in caves, in homes, in the complicated mountainous terrain of the south. So if Israel wants to disarm them, they would have to enter on the ground and search for them, 'like a needle in a haystack'. Timur speaks from the Olympian height of someone who's seen it all; and yet he doesn't understand the timing of this adventure, why Hizballah decided to take those two hostages now, why Israel responded with such overwhelming violence. Maybe because they're smarting from the humiliation of the unilateral withdrawal from the south in 2000: 'Never humiliate an army.'

Fadia, the proprietor of the Ras Beirut Bookshop, says 'We [Lebanese] can be okay with just a cup of water, and even have enough for everybody; that's why they want to destroy us'. Three years ago I was telling Fadia about my research comparing Islamic art and computer art, both of which eschew figurative images, and she, a Greek Orthodox, said 'The Orthodox 
icons also are non-figurative-you don't look at the picture [of the saint or Mary or Jesus] but past it to God'.

Frankly today I'm weepy and badly slept. It is helping me a lot to write to you as my upper lip starts to wobble.

Love, Laura

\section{— Subject: Letter from beirut July 19}

Last night at the bar sat in on a fascinating conversation between Timur Goksel and this terrific woman who's a writer for the Sunday Times, Hala Jaber. They ask, you're Canadian? Why are you going? I say, 'I'm in love!' Everybody laughs and they say, in that case you can go, that's the only reason. Both of these veterans-Hala wrote one of the first books on Hizballah; she's just returned from Iraq, she's here 'on vacation' and determined to work on her tan whether the Israelis like it or not. Fantastic woman-both are stymied as to why Hizballah decided to do this maneuver (to kidnap the 2 Israelis) now. Hizballah plans everything to a T. Then there's a big terminological debate, with me the Canadian as judge: did Hizballah miscalculate or misjudge? Much laughter and a toast, 'I am just a Turk', Timur says; they misjudged. Timur says, 'They [Hizballah] are in love!' We all laugh a lot and I make as though blushing.

But otherwise they have a solid analysis. Why it's been quiet the past $11 / 2$ days, no bombing? Timur: the haze. Israeli smart weapons rely on laser and it doesn't work when it's hazy. Listen, they have operators on the ground who 'paint' a target, as small as an apartment on a certain floor, with a laser. The Israeli pilot only needs to push a button and the missile finds the laser-lit target. Who are these people on the ground? Palestinians, refugees living in Lebanon. Broken people, tortured, threatened, a brother in prison, they're going to die anyway but their family will be in trouble for 50 years if they don't cooperate. Timur says today Hizballah captured maybe 5 of these agents.

Bassem likes movies about nature; mountains, prairies, water, especially water. We talked about March of the Penguins, the males huddled together protecting the eggs. I told him about the violent life of Vancouver: sea otters menacing fish! Seagulls devouring starfish! Attached is a letter to the newspaper, feel free to copy it.

Love, Laura

\section{- July 19}

Today I shopped around for some agate worry beads for young Bryan (my gemstone-loving nephew) as promised and found some in an antique shop. I tell the proprietor in Arabic that 
I'm an art history professor, and the fellow visiting the shop says he's a sculptor and invites me to his gallery. As we walk along, Nadim, who's from Palmyra, says since childhood he knew he could make sculptures like the ancient ones around him. He says 'My work is in the Metropolitan Museum in New York! And in Paris! But not signed!!' Gradually my brain glommed on to the fact that he make fakes!! He sold a sculpture to a friend for $\$ 500$ who sold it in New York for $\$ 25,000$. Ha ha ha!

We went to his shop, across from Patisserie Taj Al Molouk, a cool dusty place packed with ancient-looking busts and statues, and his signed artworks too, surreal paintings and drawings, political and sensual. He gave me tea, a necklace, and a book he wrote demonstrating that all world religions are one, which I promised to be able to read in two years. (To protect him from spies from the Met, I have changed the name of the artist and the patisserie.)

Sohail is out of soft drinks. While I was sitting with him a little Filipina maid came in, in maid's uniform and baseball cap, to buy three packages of Kotex. He fetched them down from the top shelf with his hook on a stick. A houseful of menstruating women too scared (or lazy) to go out. The Ria brand 'tampóny' I buy here are from Bratislava. Menstruating women of the world unite!

There are lots of other foreigners here in Beirut who are of course not going anywhere: the housemaids from Sri Lanka and the Philippines, the menial laborers from Sri Lanka and Somalia who collect the garbage and clean the streets, wandering solitary with long-handled trash-picking implements, wearing the green and red Sukleen uniforms. And it seems to me there are many more Sudanese here than 2 years ago, refugees from their own ghastly terror. It is nice to see Africans here. One Sudani fellow labors up the road by my building every day on that rarest of Beirut vehicles, a bicycle. And at least two of the dead are Sudani and Sri Lankan.

- JULY 20

Last night I did a live radio interview with CBC British Columbia. I am proud of it. I diverted attention from the anxiety of waiting Canadians to idiotic Cdn. foreign policy, war crimes, and the incredible kindness of the Lebanese people. And right on cue there were two big echoing Boom Booms. You can hear it online somewhere.

I am not eating well cuz of knot in stomach. Bar peanuts are my friend. Yesterday fiftyseven people were killed and the refugee toll is at five hundred thousand. Here's how Marc Sirols of the Daily Star puts it: 'As of Wednesday evening, Israeli attacks had killed at least 260 civilians in Lebanon', while 13 Israeli civilians have been killed by Hizballah. 'Lebanon has approximately 3.5 million people. On a per-capita basis, that means that as of Wednesday, the rough equivalent of $9 / 11$ has happened here every day for eight days.' 
On another note. Li has been staying in one of the men's dorms on campus, emptied of the evacuated Americans. Yesterday several Shi'a women refugees moved into the building. Normally people of the other sex are not allowed in after $11 \mathrm{pm}$. There's only one bathroom, so the ladies have to stand in front of the door to defend it from Li and the janitor! It is great that AUB is letting people come live here; as I've said it is the safest place in Lebanon, considered US territory.

Li Guo is a lovely American and that rare thing, a Chinese-born Arabic teacher. He's also a historian of the Mamluk period and, what is great for me, a paleographer-someone who loves to peer at old inscriptions on stone. When I was in Cairo I took many photographs of the Fatimid mosques in Cairo, $10^{\text {th }}-12^{\text {th }}$ Cs, especially their mysterious Kufic lettering that intertwines and sprouts vines and leaves. Some argue that the inscrutable nature of floriated Kufic lettering reflects the emphasis in Shi'a Islam on latent meaning and interpretation (the Fatimids were Shi'a). I'm hoping Li and the native Arabic readers here will help me decipher the inscriptions and understand the nature of their difficulty.

I'll go donate some blood at the hospital. Maybe the recipient will get drunk for the first time in her life! (Joke. It's noon here. I'm not drinking.)

Love, Laura

\section{— JULy 2O, LATER}

Frankly I'm depressed. Now I feel a bit of what it's like to be in a war, or more accurately, besieged, rather than to be leaving one. Have to unpack some things. Went to buy food. There's not a lot. There's no big bottles of water left. Wanted Halloumi cheese; the fellow sold me Bulgarian feta. Because trucks can't come in with food. Worse, Liban Lait, the largest milk company in the country, was bombed.

The building is full of refugees, girls playing in the stairway, boys moving concrete things in the parking lot. I had a child's book in Arabic, about a moutain that fell in love with a bird. Took a leaf from Rick, my honey, who always has books around to give to kids, and offered it to the girls. They immediately took it to a mom in the lobby to read to them. So I went to Ras Beirut Bookshop and with Fadia's advice bought a bunch of books for different ages, with pictures, and some magazines. Brought them back for Charlie the afternoon manager to distribute, and he did.

I told Madame Souad, who oversees the cleaning of the apartment building, that I was leaving and she could have my soap, cooking pot and vase. She misunderstood and took more than that from my apartment. Negotiated the release of my kitchen knife, cutting board and corkscrew. 
Actually I ate well tonight: frozen cheese sambousek, frozen artichokes, tomatoes, the delicious indescribable vegetable called me'te, and Farida's olives. I read The Book of Saladin, taking comfort in wars of 800 years ago. Felt that I'm very well off.

Thanks to my computer I can gaze at a picture of my beautiful Rick and me, smiling, and at the same time listen to Rima Khcheich singing love songs in her limpid voice, all while sitting on the balcony in the quiet night. I love my computer. I love electricity. The neighbors' TV across the way for once not tuned to the news; women chatting in the street; a cat prowling in the parking lot's potted garden. Then comes one thunderous Boom, maybe from the port, and another, and the neighbors start channel surfing again.

Love, Laura

\section{- JULY 22}

Hello dear ones,

Am a bit sunburnt: went to what was supposed to be a 10-minute vigil for the dead at Martyrs' Square, and although there were already more press than participants, we waited an hour for the live TV to show up.

Hisham says hi to Janine and thanks for the kiss. His relatives were escaping from the South on a motorcycle. They thought the motorcycle would be safer because the Israelis would see them and would not bomb them. Well, an Israeli plane saw them and they did bomb them, killing father and mother; the five-year-old is now in hospital. I am holding back tears as hard as I can as I write this, but I want you to cry and be angry and do something. Sorry dear ones.

It's 6:10. The Israelis told people in 13 villages in the south that they have until 7 tonight to leave. Leave how? The roads are destroyed. Lots of old people are just staying. Remind you of anything?

Meanwhile the ships are passing in and out of the harbor. The Lebanese watch them go with dread. I do too, I have already told you why. As of this morning the Americans have evacuated 3500 people (some friends from the university went out in a dramatic helicopter airlift at 5 this morning), the Canadians about 2500. Not such a disparity-considering that three of the ships the Americans are using are Canadian! What's that about?! But I do not want to go the American way because, while their web site promises air-conditioned lodgings with cots, in fact some Americans are camping on a Cypriot fairground. I prefer the Canadian way because I don't know what it is. The Canadians have been quite mum about what happens to folks once they arrive in Cyprus or Turkey. 
A quiet day, other than two big bombs in Dahiyeh at 2:30 at night and another just now. The fighting is in the south and there is not much news yet. It's hot and bright today and down at the rocky beach are lots of bronzed boys and men, fishing and swimming and smoking arguileh. On the horizon beyond them, the ships glide away from the port.

I am well though I have nasty dreams I don't remember.

Lebanese pride is asserting itself. Got some Tshirts last night: 'Beirut, a city that will never surrender.' (see SaveBeirut.org) Wore one out this morning and the first people I saw, Naji and Ahmed at Snack Faysal, coaxed me out of it if you know what I mean, and all the stickers too. If the Israeli army comes to Beirut, people will be ready for them. Hisham reminds me that every Lebanese man knows how to shoot.

Hani is okay! They had to leave their house in Jiyeh because it's next to a bridge. His middle boy Ahmed (the fourth Ahmed in this story) was in an accident 3 days before the war started—a journalist speeding in a Jeep hit him—and he had to have surgery on his pancreas. He is okay and Hani is ever the optimist. Both he and Ahmed (the first) say this is the last war Lebanon will have.??

Love, Laura

- JULY 28 AM

Hi dear ones. am in montreal going to vancouver tomorrow. news later of harrowing journey of boatful of souls.

laura

- JULY 28

Hi dear ones. I am writing to you from a hotel near the Montreal airport.

What to tell you about this journey? Back in Beirut when interviewed about the slow Canadian evacuation I said I'd be patient. But after the hideous experience 400 of us went through to get to Montreal I see there's a political problem here that extends beyond incompetence into racism, because $95 \%$ of the passengers were Arab-Canadians. If Canadians had been evacuating from, oh, France or Japan, would they have been treated like animals? Lebanese are dignified people and we were treated like cattle.

Anyway to be specific. Journey begins with many many hours in a huge air-conditioned conference center near Beirut port, getting 'processed' and waiting. From the windows we admire the vast cruise ships in the harbor. Then we get on buses, which swing along the dock, past the cruise ships, to an tiny and ancient Turkish ferry. ('You'll be looking for a man 
named One-Eyed Willie', some Red Cross jokester said to our bus driver. 'Sorry, can you repeat more slowly?', the driver replied.) We pile in and wait as the ferry fills, and fills more, until 400 souls are packed on a boat meant for 150. The A/C doesn't work. Quickly many of us seek the comfort of the deck and there we watch Beirut recede. As we watch, Dahieh is bombed again, 3 times and the smoke rises in mushroom clouds.

We'd been told it would be a 6-8 hour trip, but the great cruise ships speed by, and people start trying to extract information from the Turkish crew (no Canadian reps on board, no medics), and the news comes out: 20 hours. Soon the hellishness of our conditions become apparent. Inside the cabin it is unbearably hot and stinking. The toilets overflow. No toilet paper; I hoard tissues like gold. People fill all the chairs, the café benches, and the floors. Children howling. Mothers try to keep flies off their babies' faces. One poor woman traveling with her 4 children got seasick and fainted. I happened to see her baby crawling up the stairs to the deck, grabbed him, and handed him to someone who knew where he came from. Many of us resort to sleeping on the iron deck, which is only unbearable as opposed to absolute hell inside. The deck fills with our sleeping bodies, resting heads on pieces of cardboard; a mom and daughter use a guitar case as a pillow. Out here it is cooler but the stench of diesel and tar is overwhelming. Nowhere on the boat can I draw a good breath.

Next day the heat rises. The only food available is for sale in American small bills. (I convince them to take Canadian.) We seek shelter in the small shadows of the lifeboats. Our clothes and the ladies' veils are ruined with drips of tar spewing from the smokestack.

I have to say there was a camaraderie and caring among us, people looking out for each other. Had some fascinating conversations to pass the time. Yusuf, originally Palestinian, who now owns a Hasty Market in London Ontario, taught me some beautiful poems in Arabic. His young wife traveling to Canada for the first time. Some people live in Canada and visit Lebanon, or really manage to divide their time between the two. Well-to-do people wearing a fortune in gold jewelry. More heart-wringing are the families who have lost everything and are traveling to one relative in Canada, or people who left their families behind and hope to bring them later-their life is on a shoestring. But the physical discomfort is such that it's hard to think of the future or of what's happening in Lebanon. I cannot overemphasize the many kinds of stench.

The point is this evacuation was a scandal. A few people who have 2 citizenships said 'Forget Canada. It's obvious we're not welcome.' We said, 'So much for multiculturalism'.

We arrive in Mersin, Turkey. 2 hour wait in stinking hot passport control. We are given pretzels and juice. Our clothes are soaked through with sweat and it is again like hell. Here finally are some Canadian workers, with vague information: 'You are going to a stadium in Adena to rest while you wait for your flight.' Uh-oh, euphemism control! 'Rest'?? 
A 2-hour bus ride. I don't know where all these places are. The stadium is, after what we've been through, paradise: it's air-conditioned, we all get a fresh towel and a bar of soap, and the place is paved with thin blue mattresses that feel divine after the iron deck. The food is good, the mayor of Adena donated kebabs. We wait, wait, and wait. The din of voices and children crying disperses around the stadium. We can't leave the building except to walk on the small grounds, where the Turkish people observe us through the fence like zoo animals. I notice the calm and simplicity of life here: slow-paced bicycle riders, 3 on a tiny motorbike, laundry and grape vines on the roof.

Some of our number get onto planes that night. Only about 150 are left to retire to our heavenly 2 -inch foam mattresses till the morning. We wait, wait, and wait. There's one telephone, one TV. When Turkish CNN shows Lebanon we gather round to try to decipher: body bags; two babies in a morgue; Israeli tanks penetrating the south; Israeli soldiers practicing on virtual reality, which obscenely shows buildings and not people. Some of us weep.

After 24 hours (I cannot describe here how I and others try to fill time; I gained a few hours from a brilliant novel, Zayni Barakat, about espionage and total surveillance in $16^{\text {th }} \mathrm{C}$ Cairo, a Foucauldian nightmare much like the present) we get the call and are elated. The rest is slow but well-organized: bus, wait, 12-hour flight to Montreal via Shannon. We gather around American CNN in the Irish airport and the story is much different: no pictures of Lebanese dead, lots of info on Israeli strategy and Nasrallah-hunting, Condoleeza playing the piano in Japan. My heart is broken for Lebanon, and I had less to lose than all my fellow passengers.

Now I will fly to Vancouver. Love to you all.

Laura 